\title{
Russia and Peacekeeping Operations: Conceptual and Practical Components of Russia's Policy ${ }^{1}$
}

\author{
M. Bratersky
}

Maxim Bratersky - Professor in the Department of International Affairs, National Research University Higher School of Economics; 20 Myasnitskaya St., 101000 Moscow, Russian Federation; E-mail: mbratersky@hse.ru

\begin{abstract}
Historically, the central principles of international peacekeeping have been formulated by western powers due to their political and ideological domination in international institutions, including the United Nations (UN) family. It is only recently that emerging powers, among them Russia and China, have started to formulate their own policies of peacekeeping and to implement them in practice. While the general objectives of peacekeeping as understood by western nations and emerging powers are similar, there are differences of emphasis. Recent developments in Syria and the active involvement of Russia in these events have underscored the nuanced views these two approaches hold on peacekeeping in general and on outside involvement in peacekeeping operations.

For the United States and many European countries, the goal of peacekeeping and conflict resolution is to protect individual rights and freedoms and to accomplish a "democratic transition" by replacing authoritarian regimes with liberal-democratic alternatives. For Russia as well as many other emerging powers, the goal of conflict resolution and peacekeeping is to preserve and strengthen the local state structures so that they can support law and order on their territory and stabilize the situation in the country and the region. The western approach assumes that donor countries know better what to do with regard to local problems, while a "rising powers" approach is far less dogmatic and recognizes the right of actors to make mistakes along the way.
\end{abstract}

This article focuses on Russia's approaches to peacekeeping as they are defined theoretically and practically.

Key words: peacekeeping; peacebuilding; operation ownership; sovereignty

For citation: Bratersky M. (2018) Russia and Peacekeeping Operations: Conceptual and Practical Components of Russia's Policy. International Organisations Research Journal, vol. 13, no 1, pp. 157-170. (In Russian and English.) DOI: 10.17323/1996-7845-2018-01-09

Russian participation in the conflict in Syria (which many commentators would call a civil war) clearly reveals disagreement between Russia, China, Turkey, Iran and official Syria on one side and major western powers on the other regarding the major principles and policies of modern peacekeeping. Being systemic in character and resulting from different national interests in the changing world order, these disagreements involve several main components of peacekeeping. First, there are different views about the appropriate balance between ideology and values on one side and realistic pragmatism on the other, and on the extent to which the international community or powerful countries have the right to take sides based on their own interpretation of a conflict rather than on international legal norms. Second, in the absence of a relevant United Nations (UN) Security Council resolution there is no agreement as to whether the consent of a local government is absolutely required before foreign actors intervene to pursue their own interests in a particular outcome of the conflict.

${ }^{1}$ The editorial board received the article in December 2017. 
In this context, the Syrian conflict raised again the question of how the "responsibility to protect" principle should be interpreted, and whether it is state interests or rights of individuals that should be central to the implementation of the concept. Third is the question of what should be the immediate goal of peacekeeping efforts in conflicts like those in Syria the reestablishment and preservation of a state capable of fighting terrorists, or protection of human rights and the establishment of democratic rule?

The Syrian conflict received unprecedentedly politicized coverage which produced one-sided representations of the conflict on each side of the ideological divide. Western media presented a very particular picture of the conflict and Russia's role in it. A totally different picture was presented in Russia, China and many other countries. This issue should attract the attention of scholars of international relations and peacekeeping, and the importance of interpretation, values and ideology should be recognized in international peacekeeping practice and theory.

This contribution considers sources of Russian policy toward international peacekeeping focusing on Russia's motives and understanding of international relations, including the place of peacekeeping in international politics. Details of Russia's contributions to international peacekeeping will also be explored. The main argument developed in this article is that Russian peacekeeping is no longer ideologically based - it is neither communist nor liberal. Instead, the Russian approach to peacekeeping is based on the philosophy of a multipolar world where no nation, group of nations or single system of values dominates.

\section{Russia's Peacekeeping Policies}

The second crisis of the global international order (with the first provoked by the end of the Cold War) was marked by the growth of the number of conflicts and civil wars stemming from religious, sectarian and ethnic contradictions. The world order became split over basic policies and issues and was ineffective in resolving conflicts. The main lines of division in the world system were drawn along ideological tectonic plates which formed around specific economic and security interests of countries and the elites within them. Great powers significantly disagreed in their vision of the roots of such conflicts and the ways to resolve them.

For Russia as well as many other emerging powers the task of conflict resolution and peacekeeping is to preserve and strengthen local statehoods so that they can support law and order on their territories and stabilize the situation in their countries and the region.

For the United States and many European countries, the goal of peacekeeping and conflict resolution is to protect individual rights and freedoms and to accomplish a "democratic transition" by establishing liberal-democratic regimes to replace authoritarian ones. The West's position on peacekeeping in past decades was shaped by a liberal ideology with elements of interventionism, while Russia's position was increasingly defined by etatism and nationalism. Given that ideology, interpretation and various political concepts had such a bearing on peacekeeping policies in the last several decades, it is important to focus on Russia's perspective and the motives for its support or rejection of particular peacekeeping operations. 


\section{Russia's Stance on the Place and Role of the UN in Peacekeeping}

Russia considers peacekeeping to be one of the main functions of the UN. According to Russian Minister of Foreign Affairs Sergei Lavrov, Russia consistently places great importance on peacekeeping as a significant instrument to reduce the level of conflict in international relations and manage the crises that continue to present a threat to international law and security in our turbulent times. Lavrov notes that "Russia plays and will continue to play an active part in the development of preventative anti-crisis potential of the $\mathrm{UN}$, which includes assigning UN peacekeepers for operations to keep the peace, support peacekeeping operations, and preparing for peacekeeping contingencies" [Lavrov, 2013].

Support of UN peacekeeping activities should be viewed in the context Russia's broader policy toward the UN. In its vision of the world and the changing world order, Moscow attributes enormous importance to the United Nations and its central place in the global political architecture. There are two reasons for this. First, Russia is by no means a revisionist power. On the contrary, it is and has been a status quo power (although some experts would argue that Russia is in fact a "declining power") that insists on preserving the YaltaPotsdam international system in its original incarnation [Scott, 2007, p. 99].

This approach is understandable. Under the current conditions of relative weakness in comparison to the U.S. and its allies that increasingly view Moscow as a competitor and even opponent, the system of international law established after World War II grants Russia the right to preserve its own position. Even the more assertive actions of Russia to defend its own interests, for example in relation to Georgia in 2008 and Ukraine in 2014, should be considered not as revisionist initiatives, but as reactions to actions of the West, which from Moscow's perspective, seemed intended to change the status-quo by bringing more and more territory into its sphere of influence. The United Nations has always served as the central pillar of the post-WWII international system in which the then-Soviet Union was guaranteed a central role in the system by its permanent membership in the Security Council, augmented by its veto power.

Another reason for Russia being supportive of the UN's central role in the world system, including its peacekeeping responsibilities, lies in the fact that the outlook of the current leadership of the Russian Federation sees the world as a competitive arena in which nations promote their national interests as illustrated in the observation that "tensions are rising due to disparities in global development, the widening prosperity gap between States and growing competition for resources, access to markets and control over transport arteries. This competition involves not only human, research and technological capabilities, but has been increasingly gaining a civilizational dimension in the form of dueling values."

Russia's perspective is informed by several key assumptions, the most important of which are the acceptance of the fact that every nation has national interests and that nations should seek compromise between their interests. Russia believes that the United Nations is the key mechanism for seeking compromises among nations and that it is the only insti-

${ }^{2}$ Foreign Policy Concept of the Russian Federation. Approved by President of the Russian Federation V. Putin on 12 February 2013. Available at: http://www.mid.ru/en/foreign_policy/official_documents/-/ asset_publisher/CptICkB6BZ29/content/id/2542248. 
tution which could, despite all its problems, make the world political situation stable and predictable . Alternative concepts of world order are unacceptable. In sum, Russia sees the world without the central role of the UN as dangerous, unpredictable, prone to conflicts, and unfair. Putin made this view very clear in his speech at the 70th session of the UN General Assembly on 28 September 2015, noting that "we consider any attempts to undermine the legitimacy of the United Nations as extremely dangerous. They may result in the collapse of the entire architecture of international relations, and then indeed there will be no rules left except for the rule of force. The world will be dominated by selfishness rather than collective effort, by dictate rather than equality and liberty, and instead of truly independent states we will have protectorates controlled from outside." 3

This stance on the UN's world role has always been central to Russian foreign policy and has been confirmed by all Russian administrations in all foreign policy documents. The current Foreign Policy Concept of the Russian Federation of 2013 reads:

The United Nations should remain the centre of international relations and coordination in world politics in the 21st century, as it has proven to have no alternative and also possesses unique legitimacy. Russia supports the efforts aimed at strengthening the UN's central and coordinating role. ${ }^{4}$

Russia rejects any attempts to reform the UN that risk undermining its central role in the world system. Commenting on the various ideas raised in discussions of UN reform, Vladimir Putin insisted that "we should move toward reform on two main conditions. First - this should be a result of a broad consensus... The second compulsory condition is to maintain the fundamental principles of UN efficiency; in particular, the prerogatives and rights of its Security Council." 5

Many observers have noted that while extending support to the United Nations Russia has also sponsored the creation of some powerful coalitions of countries like the Shanghai Cooperation Organization (SCO) and the BRICS grouping of Brazil, Russia, India, China and South Africa. From the Russian point of view, there is no discrepancy between these policies; rather they are understood to complement each other. ${ }^{6}$

\section{Peacekeeping as an Integral Part of Russia's Foreign Policy}

Peacekeeping operations - at least in the "near abroad" of direct strategic interest to Russia are considered by Moscow not only as an instrument for keeping the peace and resolving humanitarian problems, but also as an important leverage of foreign policy in the pursuit of protecting the national interest. It is worth mentioning that in this respect, Russian approaches to

\footnotetext{
${ }^{3}$ Available at: http://en.kremlin.ru/events/president/news/50385.

${ }^{4}$ Foreign Policy Concept of the Russian Federation. Approved by President of the Russian Federation V. Putin on 12 February 2013. Available at: http://www.mid.ru/en/foreign_policy/official_documents/-/asset_publisher/CptICkB6BZ29/content/id/2542248.

${ }^{5}$ Seliger 2014 National Youth Forum, 29 August. Available at: http://eng.kremlin.ru/news/22864.

${ }^{6}$ Obzor MID Rossii Vneshnepoliticheskaya i diplomaticheskaya deyatel'nost' Rossiiskoi Federatsii v 2015 godu [Review of Foreign Policy and Diplomatic Activity of Russia in 2015]. 26 April 2016. Available at: http://www.mid.ru/foreign_policy/news/-/asset_publisher/cKNonkJE02Bw/content/id/2255624\#Участие России в «Группе двадцати» и БРИКС.
} 
peacekeeping differs little from those of other major powers, all of whom take the decision to initiate or participate in such operations based on their own national interests. This pragmatic approach to foreign policy forms the basis on which Moscow determines its approach to a full range of issues related to peacekeeping.

One of the most important and persistent interests of Russia is peacekeeping on its borders, although for Russia peacekeeping operations can serve additional political purposes as well. Russia sees its participation in peacekeeping partially as an element of national security policy, and public opinion favours the dispatch of Russian soldiers within Russia's security neighbourhood much more strongly over their service in distant countries. It can be also argued that modern Russia is not like the Soviet Union; while the latter had global interests, Russia's priorities tend to focus on the local neighbourhood.

All other factors being equal, Russia tends to support peacekeeping efforts aimed at preserving the status quo. Russia's view is that a legitimate existing government would have more credibility and support than the groups willing to topple it for whatever reasons.

Russia views peacekeeping first and foremost as a component of its foreign policy, and thus various approaches to resolving a situation are assessed in terms of the extent to which they serve Russia's national interests. Such a foundation in many ways determines the position of Russia with respect to the new peacekeeping structures and objectives that the international community has witnessed in recent years.

As of early 2017, Russia has participated in nine UN peacekeeping missions, and only one peacekeeping mission outside UN. Missions sponsored by the Russian Commonwealth of Independent States (CIS) in Abkhazia and in South Ossetia were terminated upon recognition of their sovereignty by Russia, and their facilities were transformed into Russian military bases abroad. Agreements within Collective Security Treaty Organizations (CSTO) on the establishment of CSTO peacekeeping forces exist, but they have not yet been enacted. As for the Russian military presence in Syria, Russia calls it "an anti-terrorist operation," not a peacekeeping one. ${ }^{7}$

\section{What Kind of Peacekeeping Operation Does Russia Consider to be Legitimate?}

Russia's vision of the role of the UN in international peacekeeping is grounded firmly in its view of the organization's role in world politics more generally. First and foremost, Russia holds that international peacekeeping missions as a rule must be sanctioned by the UN Security Council. To some extent Russia also accepts the possibility of peacekeeping on the basis of intergovernmental agreements and recognizes the special role that regional organizations often play in initializing peacekeeping missions. However, Moscow's acknowledgment of this role is based on such organizations acting strictly within the geographical frameworks in which they are based. In other words, according to Russia, a peacekeeping mission should ideally be authorized by the UN. Regional organizations and individual nations may also engage in peacekeeping, but only based on an intergovernmental agreement

${ }^{7}$ Briefing by Foreign Ministry Spokesperson Maria Zakharova, Moscow, 27 October 2016. Available at: http://www.mid.ru/en/foreign_policy/news//asset_publisher/cKNonkJE02Bw/content/id/2507489. 
or on the territory of the members of the organization. Peacekeeping missions outside of these legal premises are viewed as morally doubtful and are often considered to be in violation of international law (for example, the initial phase of the operation in Iraq in 2003 without a mandate and the breaching of the UN mandate in Libya in 2011).

Russia shares the view that UN peacekeeping operations have not been sufficiently effective and that there is a pressing need for reform in this area. Specifically, Russia believes that many modern UN peacekeeping operations are given mandates that are too complex and unrealizable, that basic principles such as consent of the receiving party, neutrality and non-use of force are being increasingly ignored, that modern peacekeeping missions are placing excessive emphasis on robust peacekeeping and that the role of the receiving government is being downplayed [Gilmutdinova, Ramadan, 2016].

The stance of Moscow on the approach of the West in regard to peacekeeping has undergone a series of changes. Immediately after the fall of the Soviet Union, Russia sought a new identity as a part of the West and began to actively participate in international peacekeeping, fully sharing the goals of the West. The first crisis began with the peacekeeping operations in the former Yugoslavia. In the opinion of Moscow, during the course of these operations the U.S. and the North Atlantic Treaty Organization (NATO) used the Security Council mandate to achieve its own political goals rather than to end the conflict. Punishment of the Milošević regime and the breakup of Yugoslavia and subsequently of Serbia led to serious disapproval of the West in Russian political circles.

Criticizing these and similar actions by the U.S. and its allies, some of the Russian experts came to the conclusion that:

Toward the middle of the 1990s, the signs of a crisis in the UN's peacekeeping operations became obvious, and the international community began to search for a way out of the crisis. The crisis in UN peacekeeping is deeper than it seems at first glance, its roots can be found not only in the shortcomings of the crisis-reaction system itself, but also in weaknesses in the international legal system as a whole [Kuz'mina, 2013, p. 74].

These and other situations heavily influenced the position of Russia on reform of the UN peacekeeping system. This position came to be based on the belief that the formation of active mechanisms of crisis prevention, continuous improvement of peacekeeping practices and strengthening the foundations for both must take place under strict supervision of regional organizations, but always with the Security Council playing a central role.

Formulating this position, the assistant director of the department of international organizations of the Russian Ministry of Foreign Affairs Vladimir Zaemskii wrote:

A new level of regulations put forth by the world community on the issue of peacekeeping activities, substantially broadened the range of goals and means for their attainment. On one hand, the established methods of peacekeeping have undergone a substantial evolution, on the other, the number of tasks that must be addressed in the course of peacekeeping operations have multiplied exponentially. The variety of forms of modern peacekeeping methods, including with the participation of regional organizations or coalitions, is a natural and necessary development, but what must remain immutable is the lead role of the UN as the only universal organization of its kind, to whose charter all members of the international community are bound to adhere [Zaemskii, 2009, p. 138]. 
In Moscow's view, the above-mentioned reform must consist of two main components: perfecting of the crisis-reaction mechanism itself and its peacekeeping potential, and the development of clear legal guidelines for the use of force in international relations. First and foremost, Russia calls for realization of a set of new measures, mainly for enhancing the quality of planning and preparation for peacekeeping operations, as well as for greater operational efficiency. The realization of this goal would require, among other things, the creation of well-trained multinational teams of 5,000 people each, which could be deployed to any hot spot in the world within a month. Political emphasis should be placed on strict adherence to the operational mandates issued by the Security Council, which in turn must be drafted in accordance with the highest standards of clarity. They must be achievable and backed up by the necessary resources.

Second, in Russia's opinion, serious work must be done to improve sanctions regimes. Russia's aim is to ensure that sanctions remain under the consideration of the Security Council and that they are reconsidered after certain periods of time upon a mandatory analysis of possible humanitarian consequences, suffering among the civilian population and evaluation of the possible negative effects of the sanctions on third countries.

Third, Russia continues to support the UN with its proposal for activating a "military staff committee," which will only be possible through the participation of all permanent members of the Security Council. Finally, Moscow also supports the expansion of partnership between the UN and regional organizations within the framework of Chapter VIII of the UN Charter. As far as Moscow is concerned, Russia is making progress in this regard, developing coordination between the UN and CIS in the area of peacekeeping. Nonetheless, Russia is opposed to the replacement of the UN by regional structures [Grishaeva, 2008, p. 143].

As far as the legal aspects of peacekeeping are concerned, Russia underlines the special importance of adhering to the fundamentals of international law as they pertain to peacekeeping, and, first and foremost, to the UN Charter. Russia, for example, has introduced a proposal at the UN on collectively clarifying the legal aspects of the use of force in international relations in the context of a globalizing world. In Russia's opinion, these legal provisions must not violate the basic principles of sovereignty and the territorial integrity of states. This necessity, from Russia's point of view, is rooted in constant violation of the UN Charter by the U.S., which justifies its actions with reference to concepts such as "limited sovereignty," "humanitarian intervention" and "responsibility to protect." Yet in reality these actions often contradict the basic principles of territorial integrity and the inviolability of national borders. ${ }^{8}$

\section{Russia's Position on the Kind of Operations the UN Should and Should Not Be Doing}

Advocating for the necessity of adhering to norms of international law in international relations, Russia calls for giving priority to early warning systems and preventative measures in preventative diplomacy. Speaking at the 54th session of the General Assembly in 1999, Russian Minister of Foreign Affairs Igor Ivanov warned,

${ }^{8}$ Vystuplenie Ministra Inostrannyh del Rossiiskoi Federatsii I.S. Ivanova na 54-y sessii General'noi Assamblei OON [Speech of Minister of Foreign Affairs of the Russian Federation I.S. Ivanov at the 54th Session of the General Assembly of the UN]. Available at: http://www.rg.ru/oficial/from_min/mid_99/285.htm. 
The founding fathers of the UN envisioned the capability of responding, on a legal basis, to the violation of peace and security. The international community can resort to coercive measures, but this must be done in accordance with the UN Charter and by a decision of the Security Council. Non-legal means can only compromise legal ends. This is precisely the view that informs our understanding of doctrines such as the concept of "humanitarian intervention." We must be exceptionally careful in our approach to any coercive measures, and even more so in not allowing them to become a tool of repression to be used against states or peoples that one or another state finds objectionable. ${ }^{9}$

Starting at the end of 1990s, international peacekeeping came under the influence of two important trends. First, it became increasingly common for regional organizations or powerful nations acting in coalitions to begin their engagement in peacekeeping operations prior to receiving a mandate from the UN. Either the actors sought a mandate from the UN after operations had already begun or they interpreted the UN mandate in such a way as to allow them to take sides in a conflict, eliminating the need for a mandate all together. The second trend came as the UN reacted to the increase in internal ethnic, religious and ideological conflicts by modifying its mandates to depart from the traditional, non-partisan nature of its decisions. These developments were seen in Russia as a threat to the existing world order and a challenge to the traditional role of peacekeeping within that order, although in some instances the changes were seen as an opportunity to advance Russian security interests. Since the end of the 1990s Russia has consistently made the point that nobody - including the U.S. and NATO - has a monopoly to violate international law. If they choose to break up the territorial integrity of a country on the grounds of the principle of self-determination (Serbia and Kosovo), they can expect the same principle to be applied by other nations in similar situations (Crimea). It may be argued that western actions in Kosovo, Iraq and Libya were seen in Russia both as a threat to the existing international order and as an opportunity to promote Russian interests in similar situations. As these trends are inseparable from discussions of the UN's overall role in world politics an analysis of how Russia views the evolving role of peacekeeping must begin with a look at how Russia currently views the world and the role of the UN.

\section{National Policies and Contributions to UN Peacekeeping}

As a legal successor to the Soviet Union, the Russian Federation inherited the Soviet Union's political assets and responsibilities regarding peacekeeping, including its central role on the UN Security Council. Russia plays an active role in all Security Council discussions concerning peacekeeping and has taken part in several UN peacekeeping missions.

Since Russia has played a substantial role in the development of UN peacekeeping procedures, there is little disagreement with the key principles developed by the UN concerning such missions: a clear mandate; the consent of the parties to the conflict to a UN intervention and deployment; the impartiality of the missions; and the non-use of force by peacekeepers except in self-defense and in defense of the mission's mandate. Another principle, which Russia considers traditional rather than official, is the non-participation of

${ }^{9}$ Vystuplenie Ministra Inostrannyh del Rossiiskoi Federatsii I.S. Ivanova na 54-y sessii General'noi Assamblei OON [Speech of Minister of Foreign Affairs of the Russian Federation I.S. Ivanov at the 54th Session of the General Assembly of the UN]. Available at: http://www.rg.ru/oficial/from_min/mid_99/285.htm. 
military contingents from great powers in peacekeeping missions. This tradition originated from the 1974 protocol of the agreement between Israel and Syria and although it is not official policy, Russia has generally preferred that peacekeeping missions be mostly staffed with military personnel from "third" countries.

In 2015, Russia had 84 peacekeepers in the field under UN auspices (68 military observers and 16 police officers) who were taking part in nine UN missions out of 16 . The number of peacekeepers sent by Russia roughly corresponds to the number of U.S. peacekeepers (82) or Germany (172). This was a small number compared to such countries as Bangladesh, for example $(9,400)$.

The number of Russian peacekeepers is smaller than in the previous year when there were 92 personnel assigned to UN peacekeeping missions, including 29 police officers, 60 military observers and three troops. This number is lower than average for Russia, which as recently as 2010 had 366 personnel (55 police officers, 77 military observers and 239 troops) actively assigned to UN peacekeeping missions. Russian personnel have served with missions in Western Sahara (MINURSO), CAR and Chad (MINURCAT), Haiti (MINUSTAH), Cote d'Ivoire (UNOCI), the Democratic Republic of the Congo (MONUC), Kosovo (UNMIK), Liberia (UNMIL), Sudan (UNMIS) and East Timor (UNMIT). Russian (then-Soviet) participation in UN peacekeeping missions dates back to the UNEF II mission in 1973 when, after three days of fighting, the first group of Soviet officers arrived in the Middle East and on 26 October received the status of UN military observers.

The largest military contingent ever dispatched by Russia for a UN mission served in the former Yugoslavia. On 6 March 1992 the Supreme Soviet of the Russian Federation passed a resolution sending 900 Russian peacekeepers to Bosnia and Herzegovina, 400 of which were transferred to Kosovo in 1999. In June 1999, an additional 3,600 Russian troops were sent to Kosovo, where they stayed until July 2003. The most technically equipped mission in which Russia took part was in Sudan in 2006. The Russian contingent there consisted of 120 peacekeepers and four helicopters.

The striking difference in the number of troops Russia usually contributes to UN operations, and large contingent sent in the beginning of 1990 to Kosovo, Bosnia and Herzegovina partly has domestic political explanations. It is also explained by the beginning of the crisis in the political relationship with the West at the end of the 1990s primarily over issues related to Serbia and Kosovo. This crisis opened a new reality for Russia, for which it was unprepared and to which it did not know how to react. Sending peacekeepers was not part of a considered plan, but was rather an instinctive reaction to the open violations of international law and Russia's interests in the Balkans.

Russia's contribution the UN peacekeeping budget is only about $2 \%$. According to the leading Russian expert Alexander Nikitin, this "reflects the fact that while Russia pays its assessed contributions for UN peacekeeping it does not make significant additional voluntary contributions" [2013, p. 163]. At the same time, Russia is the second-largest supplier of contractor services. "In 2011, Russian companies held contracts from the UN worth \$382 million, which composed $14 \%$ of UN peacekeeping services. Almost all of this is comprised of aviation transportation services provided by Russian aviation and cargo companies” [Nikitin, 2013, p. 163]. 
Russia's financial contribution to the aggregate budget of UN peacekeeping operations was $\$ 262$ million in 2015.

Before the mid-1990s Russian participants in UN peacekeeping operations were trained at the "Vystrel" training Centre of the Russian Armed Forces Academy in the town of Solnechnogorsk near Moscow. After that all military peacekeepers (including those designated for non-UN-mandated regional operations) were trained in the Fifteenth Motorized Infantry Division based near the city of Samara. According to Nikitin, in the late-2000s the training system was reformed again:

Under these reforms, soldiers eligible for deployment as peacekeepers would be nominated by their division and those designated for joining UN contingents would undergo training in a Ministry of Defence Training Centre in Narofominsk, near Moscow. Since June 2005 military cadres from CSTO states became entitled to train and be certified in Russian defence academies and institutions at no cost to their governments. Joint programmes for the training of peacekeepers, anti-terror and anti-drug specialists from all CSTO countries were organized by Russian military academies [Nikitin, 2013, p. 172].

Russian police peacekeepers are trained at the All-Russian Institute for Continuous Education of the Ministry of Interior in the town of Domodedovo, which also provides training for foreign police officers. It trained about 200 police peacekeepers from Africa and 300 police officers from Afghanistan according to an agreement with the UN [Nikitin, 2013, p. 172]. The annual budget for peacekeeping operations training accounted for 800 million roubles in 2009, equivalent to USD 30-35 million at the time [Denislov, 2008].

According to the size of Russian contingents participating in UN peacekeeping operations, Russia has historically ranked somewhere between 20th and 40th, depending on the year in question; this is significantly lower than the United Kingdom, France, China and many others. Among the main factors which limit Russian participation in UN peacekeeping are its domestic situation in the immediate post-Soviet era, its focus on conflict resolution in the post-Soviet space and the tendency to pursue these activities outside the auspices of the UN [Nikitin, 2013, p. 158]. On more than one occasion, Russia discouraged or directly opposed the involvement of peacekeepers from outside of the region, be it under UN or Organisation for Economic Co-operation and Development (OECD) auspices, in conflict resolution in the post-Soviet space. Good examples of such policies would be Trans-Dniester standoff and Donbas crisis.

\section{Russian Policy Toward Regional Organizations in Peacekeeping}

Russia regularly emphasizes the special role of regional organizations, which in Russia's view must be the core implementers of $\mathrm{UN}$ decisions in their respective regions. Major supraregional powers such as Russia must act in accordance with these general efforts - not by controlling such operations but by assisting and making important contributions to them. The following two principles give concrete expression to this position.

Leading Russian diplomats have expressed this position in multiple statements. In his closing remarks after meeting with the Minister of Foreign Affairs and International Partnership of the Republic of South Sudan, Benjamin Barnaba in May 2014, Russian Minister of Foreign Affairs Sergei Lavrov stated the following: 
Russia is convinced that the key and leading role in managing various conflicts on the continent must be played by Africans themselves. The African Union and sub-regional organizations on the continent have proven that they are ready to take the initiative and act as peacekeepers, and they deserve all necessary support from the UN and the Security Council... As far as future conflict management is concerned, in Somalia, the Central African Republic, Mali, the DRC, and the Great Lake Region as a whole, Russia as a permanent member of the Security Council will continue to play an important part in peacekeeping on the African Continent. ${ }^{10}$

Russia's commitment to participation in peacekeeping operations is also reflected in Article 19 of the Military Doctrine of the Russian Federation, which calls for Russia "to participate in international peacekeeping activities, including under the auspices of the United Nations and within the framework of interaction with international (regional) organizations." "This document serves as an official basis for Russia's participation in peacekeeping operations undertaken not only by the UN, but by international regional organizations as well. In addition to its UN commitments, Russia also participates in peacekeeping efforts on the basis of its intergovernmental agreements with other countries. Russia's first non-UN-mandated peacekeeping operations were launched on exactly these grounds.

Russian peacekeeping missions in the post-Soviet space are often criticized by the U.S. and its allies for being little more than attempts to consolidate Russian influence in neighbouring countries, for not allowing the participation of representatives from states outside the region and for obstructing the freedom of Russia's weaker neighbours to choose their own paths of development. Not surprisingly, this criticism is nearly identical to that of Russia against the U.S. and other NATO members. However, most of Russia's operations have been effective, and unlike the operations led by NATO members, for instance in Iraq and Libya, they did not cause further instability.

\section{Russia's Reaction to the Changing Nature of Conflicts and Methods of Peacekeeping}

The last decade has been marked by a sharp increase in the scope and mode of UN peacekeeping operations. There have been cases where UN forces were dispatched to protect a government against militants (Mali) and cases such as South Sudan where the UN sent peacekeepers to protect civilians in the absence of a peace agreement. Both cases represented new UN approaches which differ drastically from the traditional principles of peacekeeping.

What was the Russian reaction toward such changes? In short, Russia accepted the necessity of expanding the UN mandate to cover these new situations, supporting both UN Resolution 2100 on Mali as well as Resolution 1590 on Sudan. While Russia voted

${ }^{10}$ Vystuplenie I otvety na voprosy SMI Ministra inostrannyh del Rossii S.V. Lavrova v hode sovmestnoi press-konferentsii po itogam peregovorov s Ministrom inostrannyh del mezhdunarodnyh sotrudnichestva Respubliki Yuzhnyi Sudan B. Barnaboi [Speech and Q\&A with the Media with Russian Minister of Foreign Affairs Sergei Lavrov during the Course of a Joint Press Conference on the Results of Talks with the Minister of Foreign Affairs and International Cooperation of the Republic of South Sudan, Benjamin Barnaba]. Moscow, 26 May 2014. Ministry of Foreign Affairs of the Russian Federation, Department of Information and Press, Information Bulletin, 23-26 May 2014, p. 14 (author's translation).

${ }^{11}$ The Military Doctrine of the Russian Federation. 5 February 2010. Available at: http://carnegieendowment.org/files/2010russia_military_doctrine.pdf. 
against the U.S.-sponsored resolution on Syria in 2012, it supported the U.S. resolution on ISIL proposed in 2014. This shows that in principle Russia accepts broader readings of UN peacekeeping missions when the situation demands it, and in general is less concerned with the scale of the mission than with its objectives and political consequences.

Russia's greatest concern in regard to peacekeeping today is formulated in the Foreign Policy Concept of the Russian Federation:

Another risk to world peace and stability is presented by attempts to manage crises through unilateral sanctions and other coercive measures, including armed aggression, outside the framework of the UN Security Council. Some concepts that are being implemented are aimed at overthrowing legitimate authorities in sovereign states under the pretext of protecting their civilian populations. The use of coercive measures and military force bypassing the UN Charter and the UN Security Council is unable to eliminate profound socioeconomic, ethnic and other antagonisms that cause conflicts.

Thus it can be concluded that Russia sees two potentially problematic aspects in the changed philosophy of UN peacekeeping operations: first, that these operations may be used unilaterally for geo-political and economic gains; second that such operations, conceived and carried out for geo-political objectives, may end up causing even more chaos and instability.

Thus, modern Russian policy with regard to the form and objectives of peacekeeping operations must be viewed within the framework of Russia's strategic world view and understanding of the emerging international order. The key elements characterizing the Russian world outlook can be summarized as follows: upholding the principles of international law (with special emphasis on the principle of sovereignty), maintaining stability (with no changes to the existing configuration of the international system) and preserving the Yalta Potsdam institutions of global governance as the central mechanisms for resolving international disputes.

If these conditions are met, Russia has no objections to robust peacekeeping missions or use of force, as well as the use of modern equipment such as reconnaissance drones or other means of technical support of the UN missions.

\section{Conclusion}

In its approaches to peacekeeping as well as in other aspects of foreign policy, Russia is loath to accept the U.S.-centric international order and its unilateralism; it insists on the need for coordination between the major powers through compromise and balance of interests. This view is consistently stated in Russia's key foreign policy documents, including its most recent Foreign Policy Concept, which clearly states that "international relations are in the process of transition, the essence of which is the creation of a polycentric system of international relations." 12 The logic of Russia's world vision is as follows: first, in normal international practice, doubts shall be interpreted in favour of states rather than non-state actors; second, attempts at regime

${ }^{12}$ Concept of the Foreign Policy of the Russian Federation (Approved by President of the Russian Federation Vladimir Putin on 30 November 2016). Available at: http://www.mid.ru/en/foreign_policy/official_documents/-/asset_publisher/CptICkB6BZ29/content/id/2542248http://www.mid.ru/en/foreign_policy/official_documents/-/asset_publisher/CptICkB6BZ29/content/id/2542248. 
change, including those undertaken by means of peacekeeping operations, are illegitimate; third, mandates for a peacekeeping operation or any other kind of international intervention can be granted only by the UN Security Council or be implemented on the basis of an intergovernmental agreement (or agreement by a regional association) involving the state on whose territory such an operation is taking place; fourth, all attempts at peacekeeping without such mandates (e.g., "coalitions of the willing") are illegitimate; fifth, peacekeeping operations shall not result in geo-political or economic gains by initiating countries; and sixth, neighbouring countries have a stronger vested interest - and right - to formulate the objectives and terms of an operation than international actors from outside the region.

Russia shares the general humanitarian concerns of other members of the international community. Moscow remains opposed to violence used in internal conflicts and sees such conflicts - and peacemaking efforts - that occur in the regions where Russia's national interests are at stake as being of heightened cause for concern. It is also worth noting that Russia uses precedent as a key principle of international law. While Russia protested against granting independence to Kosovo, in 2008 it referred to the principle of precedent when granting recognition to South Ossetia and Abkhazia, and did so again when accepting the results of the Crimean referendum of 2014. Russia rejects the monopoly of a chosen group of countries to interpret or violate international law, and does not initiate such moves as a first actor.

\section{References}

Gilmutdinova D., Ramadan L. (2016) Novye tendentsii i tekhnologii v mirotvorcheskoi deyatel'nosti Organizatsii Ob'edinennykh Natsii v XXI veke. Mezhdunarodnaya zhizn' [New Tendencies in the UN Peacekeeping Activity at the Beginning of the XXI Century]. International Life, 21 March. Available at: https://interaffairs.ru/news/show/14852 (accessed 19 January 2018).

Grishaeva L.E (2008) Kosovo: Krizis Mirotvorchestva OON [Kosovo: Crisis of UN Peacekeeping]. Novyi istoricheskii vestnik, no 17, p. 143.

Denisov V. (2008) Missiyamira Rossii [Russia's Peace Misiion]. Krasnaya zvezda, 24 July. Available at: http://old.redstar.ru/2008/07/24_07/1_01.html (accessed 19 January 2018).

Kuz'mina O.V. (2013) Reforma Organizatsii Ob'edinennyh Natsii i politika SShA v period administratsii Baraka Obamy (2008-2012) [Reform of the United Nations and policy of the USA during the Administration of Barack Obama (2008-2012)]. Oykumena, no 2, p. 74.

Nikitin A. (2013) The Russian Federation. Providing Peacekeepers. The Politics, Challenges, and Future of United Nations Peacekeeping Contributions (Alex Bellamy and Paul Williams (eds)). Oxford: Oxford University Press, p. 163.

Scott D. (2007) China Stands Up: The PRC and the International System. London: Routledge.

Zaemskii V.F. (2009) Sovremennye problemy mirotvorcheskoi deiatel'nosti OON. Politicheskie issledovaniia [Contemporary Challenges of UN Peacekeeping Activities]. Politicheskie issledovaniia (POLIS), no 2 , p. 138. 


\title{
Россия и миротворческие операции: концептуальные и практические составляющие российской политики ${ }^{1}$
}

\author{
М.В. Братерский
}

Братерский Максим Владимирович - д.полит.н., профессор факультета мировой экономики и мировой политики Национального исследовательского университета «Высшая школа экономики»; Российская Федерация, 101000, Москва, ул. Мясницкая, д. 20; E-mail: mbratersky@hse.ru

Исторически основные принципы международного миротворчества были сформулированы западными державами, так как они идеологически доминировали в международных институтах, включая и институты семьи Объединенных Наций. Лишь сравнительно недавно растущие державы - среди них Россия и Китай - начали формулировать собственные принципы миротворчества и реализовывать их на практике. Основные задачи миротворчества понимаются западными странами и растущими державами сходным образом, тогда как существенные акценты политики расставляются по-разному. События в Сирии и вовлеченность в них России подчеркнули различия в нюансах двух подходов к миротворчеству в целом и в участии внешних держав в миротворческих операциях.

Для Соединенных Штатов и большинства европейцев цель миротворчества и разрешения конфликта состоит в защите индивидуальных прав и свобод, а также в осуществлении «демократического транзита» с целью установления либерально-демократического режима на месте авторитарного.

Для России, как и для некоторых других растущих держав, целью миротворчества и разрешения конфликта является укрепление местной государственности, с тем чтобы государство могло обеспечить закон и порядок на своей территории, а также стабилизировать ситуацию в стране и регионе. Западный подход предполагает, что страны-доноры лучше знают, как решать местные проблемы. Растущие державы придерживаются менее догматического подхода и признают за всеми участниками процесса право на ошибки.

Предлагаемая статья анализирует подход России к проблеме миротворчества на теоретическом и практическом уровне.

Ключевые слова: миротворчество; миростроительство; суверенитет; руководство миротворческой операцией

Для цитирования: Братерский М.В. Россия и миротворческие операции: концептуальные и практические составляющие российской политики // Вестник международных организаций. 2018. Т. 13. № 1. C. 157-170. DOI: 10.17323/1996-7845-2018-01-09

\section{Источники}

Гильмутдинова Д., Ромадан Л. (2016) Новые тенденции и технологии в миротворческой деятельности Организации Объединенных наций в XXI веке // Международная жизнь. № 3.

Гришаева Л.Е. (2008) Косово: кризис миротворчества ООН // Новый исторический вестник. № 17. C. 143.

Денисов В. (2008) Миссия мира России // Красная звезда. 24 июля. Режим доступа: http://old. redstar.ru/2008/07/24_07/1_01.html (дата обращения: 19.01.2018).

Заемский В.Ф. (2009) Современные проблемы миротворческой деятельности ООН. Политические исследования // ПОЛИС. Политические исследования. № 2. С. 138.

Кузьмина О.В. (2013) Реформа Организации Объединенных Наций и политика США в период администрации Барака Обамы (2008-2012) // Ойкумена. № 2. С. 74.

Nikitin A. (2013) The Russian Federation // Providing Peacekeepers. The Politics, Challenges, and Future of United Nations Peacekeeping Contributions / A. Bellamy, P. Williams (eds). Oxford: Oxford University Press. P. 163.

Scott D. (2007) China Stands Up: The PRC and the International System. L.: Routledge.

${ }^{1}$ Статья поступила в редакцию в декабре 2017 г. 